\title{
EDITORIAL
}

\section{VINTE E CINCO E VINTE ANOS DE EXISTENNCIA DA SOCIEDADE E DE SUA REVISTA}

A Sociedade Brasileira de Medicina Tropical e sua Revista completaram em 1987, respectivamente, 25 e 20 anos de existência oficial.

Em reunião preliminar realizada em Salvador, em 1960, da qual participaram entre outros, Aluizio Prata, José Rodrigues da Silva e Manoel José Ferreira, foram estabelecidas as bases para a fundação da nossa Sociedade, oficializada em 17 de novembro de 1962, em Ribeirão Preto, durante a sua primeira Jornada Cientifica.

Daquela jornada participaram os 40 fundadores da Sociedade, cuja lista consta dos Anais do XIX Congresso, realizado no Rio de Janeiro, em fevereiro de 1983, em cuja introdução sob o titulo "Vinte anos da realização de um sonho: a criação da Sociedade Brasileira de Medicina Tropical", relato os principais fatos daquele evento e transcrevo a Ata da fundação, que lavrei como seu primeiro Secretário.

O primeiro Congresso da Sociedade deveria ter sido realizado em Brasília, segundo o desejo do seu Presidente, Professor José Rodrigues da Silva; entretanto, devido a dificuldades politicas da época, somente pôde ser realizado em 1965, na cidade de Juiz de Fora.

As primeiras reuniões eram feitas com grandes dificuldades por falta de recursos financeiros, reduzido número de participantes e falta de apoio das instituições, que ainda não reconheciam representatividade na novel Sociedade que se organizava. A indústria farmacêutica era muitas vezes a única fonte de recursos de que se dispunha, principalmente quando o produto promissor para doenças parasitárias ou infecciosas estava em experimentação no Brasil.

Em 1967 foi criada a Revista da Sociedade, inicialmente com o nome de Jornal Brasileiro de Medicina Tropical, que seria editado pela Editora Brasileira S.A., a qual registrou indevidamente o título como de sua propriedade, obrigando-nos a abandonálo e a registrar a partir do segundo número o título "Revista da Sociedade Brasileira de Medicina Tropical", que assim permanece até hoje. Quantas lutas minhas e principalmente de Léa Camillo-Coura para mantê-la nos seus primeiros 15 anos de existência!

Aos poucos a Sociedade foi se fortalecendo e criando estimulo para o ingresso de novos sócios através dos Congressos em quase todas as capitais brasileiras, percorrendo o pais do Norte ao Sul e do Sudeste ao Centro-Oeste. Chegamos a ter mais de mil sócios nominais, embora apenas uma parte destes fosse efetivamente participantes.

\section{TWENTY-FIVE AND TWENTY YEARS OF THE EXISTENCE OF THE SOCIETY AND ITS JOURNAL RESPECTIVELY}

The Society of Brazilian Tropical Medicine and its journal complete in 1987 , respectively 25 and 20 years of official existence.

In the first meeting in Salvador among others participated Aluizio Prata, João Rodrigues da Silva and Manoel José Ferreira, who laid down the basis for society membership and function, which was officialised on $17^{\text {th }}$ November 1962, in Ribeirão Preto during the first scientific meeting.

In that meeting participated the 40 founders of the Society, listed in the annals of the XIX Congress, realized in Rio de Janeiro in February 1983, under the brief introduction "Twenty years in the realization of a dream: the creation of the Society of Brazilian Tropical Medicine", relating the principle events of the current metting, the act of foundation and signed by the first secretary.

The first congress was to be held in Brasilia due to the desire of the president Prof. Jose Rodrigues da Silva, although due to the difficulties of the period it ended up being held in Juiz de Fora in 1965.

The first meetings were held with great financial difficulties since here was no source of alloted funding and this led to reduced number of participants. Frequently the pharmaceutical industry was the only source of financial support. The amount of money was variable depending on whether the company had a promising compund for parasitic or infectious disease on trial in Brazil at the moment.

In 1967 the Revista of the Society was created initially with the name of the Brazilian Journal of Tropical Medicine edited by the Brazilian editors S.A. who registered the title as their property obliging us to abandon negociations and register the second number under the title Revista da Sociedade Brasileira de Medicina Tropical which has persisted to this day. Many battles have been tought by me and Léa Camillo-Coura to maintain the journal during the first 15 years of existence.

Little by little the Society grew and new members were added as a result of congresses in Brazilian capitals from north to south and southeast to centro west. We have reached more than 1,000 members although not all these are active. 
As diretorias eram eleitas inicialmente por unanimidade, escolhendo-se por consenso o Presidente entre as figuras mais destacadas e os demais membros entre os de maior participação na Sociedade. A aclamação dava o tom de cordialidade ao final dos Congressos, a cada dois anos. As sessōes de encerramento eram uma festa entre eleitos e eleitores. Naturalmente, com o crescimento da Sociedade, a diversificação dos interesses e a necessidade de afirmação de alguns, assistimos a algumas sessões tensas e disputadas, mas felizmente chegando a um final de conciliação. Não havia discriminação de pessoas ou de grupos ideológicos, seja na parte científica, social ou diretiva.

Preocupam-me, como preocupam ao atual Presidente, professor Zilton Andrade, em sua recente "Mensagem do Presidente" transcrita no Boletim da SBMT de maio de 1987, algumas manifestaçōes mais ruidosas, em mensagens que não refletem exatamente os interesses científicos da Sociedade, e sim, os interesses individuais e políticos de grupos, nem sempre os mais atuantes cientificamente, que desejam ocupar os espaços utilizando a nossa Sociedade como escudo. Estou certo, entretanto, que são manifestações isoladas que não refletem o pensamento democrático que sempre presidiu os designios da Sociedade Brasileira de Medicina Tropical.

Ao encerrar este curto editorial faço votos para que a nossa Sociedade e sua Revista sejam eternas, como são eternas as grandes obras.
The directing officials were elected uninanimously initially chosen by the president among the most prominent figures of members active in the society.

Initially (in the beginning), the directories (administration) were (was) elected for unanimity, choosing through concensus (agreement), the president of the Society, among the most important persons and the other members gave the congresses the aspect of cordiality; the ending sessions were a party for the elected and electors. Then, with the groth of the Society and the diversification of the interests, we could observe some tense and disputed sessions, that fortunately had concilatory endings. There was no discrimination (sellection) of persons or ideologic groups, either scientific, social or directive. Some manifestations that do not show the scientific interests of our society, but only individual political groups interests; traying to use our Society as a shield, these really worry me they also worry the actual president, Professor Zilton Andrade, as he says in his recent "Message of the president", written on the Bulletin of the Sociedade Brasileira de Medicina Tropical dated May, 1987.

I am sure that these are isolated manifestations that do not show the democratic thoughts of the Brazilian Society of Tropical Medicine.

I hope that the Brazilian Society of Tropical Medicine and its journal last forever as the greatest works of the humanity.

\section{J. Rodrigues Coura}

